\title{
Modeling Market Reactions to Auditor Changes Using Variable Selection Algorithms: A Meta-Analysis
}

\author{
Richard HOLOWCZAK ${ }^{\star}$, David LOUTON ${ }^{\star \star}$, Hakan SARAOGLU ${ }^{\star \star \star}$, Charles P. CULLINAN ${ }^{\star \star \star \star ~}$

\begin{abstract}
A B S T R A C T
Market reactions to auditor change filings have been studied over a long period in the literature. We provide a review of the literature on market response to auditor changes and identify a superset of variables used in published research. Applying methods from machine learning to optimize variable selection, we build models that explain market reaction to auditor changes. We compare the performance of our models with the performance of the models that use subsets of variables examined in a select list of studies in the literature. Our meta-analysis results in an improvement in model fit compared to the analysis used in prior studies.
\end{abstract}

(C) 2019 EAI. All rights reserved.

\section{Introduction}

Publicly-traded companies in the US are required to notify the investing public whenever an auditor change occurs. The SEC considers an auditor change to be a particularly important type of event, requiring timely and separate disclosure of these types of events (SEC 2017). The accounting literature has considered market reactions to auditor change notifications (through cumulative abnormal returns on the company's stock) in the period around the time of the filing (e.g., Blau et al. 2013; Cullinan et al. 2012; Chang et al. 2010; Knechell et al. 2007).

In most studies of the market reaction to auditor change, there is a specific variable (or set of variables) that are of particular interest to the authors. The authors then add control variables to ensure their findings are robust, and not related to other factors that may be correlated with their variables of interest. The inclusion of control variables has often been ad-hoc, without clear empirical grounding. This approach could make the results susceptible to change or misinterpretation if different control variables are considered or not included in the regression models.

Given the recent improvement in the availability of data in many fields, researchers have been increasingly using methods that involve data-driven inference in which they start with high dimensional data with many variables and shrink the data to a small number of variables that can enter their model through variable selection methods. Studies in the scientific literature show the advantage of incorporating variables selection processes into meta-analyses, which summarize and synthesize evidence from multiple studies, in order to improve model interpretation and prediction (Liu, et al., 2010; Li, et al., 2014; He, et al., 2016). For example, recent advances in biotechnology have led to the generation of many high-dimensional gene expression data sets that can be used to address similar biological questions. Meta-analysis plays an important role in summarizing and synthesizing scientific evidence from multiple studies.

When the dimensions of datasets are high, it is desirable to incorporate variable selection into metaanalyses to improve model interpretation and prediction. Belloni, et al. (2014) present an overview of methods that can be used in the estimation of structural models to provide high-quality inferences about model parameters. Variable selection has been increasingly applied to studies in finance and economics. Motivated by the need to find practical tools for applied econometricians to estimate demand with large numbers of variables, Bajari, et al. (2015) survey machine-learning methods and apply them to the problem of demand estimation. They propose a method of combining the surveyed models via linear regression. They show that their approach is robust to many regressors and combines model selection and estimation. In more recent work, Feng et al. (2017), Freyberger et al. (2018), and Han et al. (2018), and Rapach et al. (2018) use machine learning methods to deal with high-dimensional data in finance. Machine learning methods for variable selection have gained increasing attention among researchers and have been proposed as alternatives to stepwise selection methods, which has several shortcomings. Specifically, concerns with 
stepwise methods include (1) the coefficient values are biased upward, (2) the standard errors of model coefficients are biased downward, (3) the p-values are biased downward, (4) the results are sensitive to the number of predictive variables, and (5) the R-squared values are biased upward (Derksen, et al.; 1992; Harrell, 2001).

We contribute to the accounting and finance research through a review of the literature for market response to auditor changes and by developing a meta-analysis based variable selection process. We then use this process to build a model that improves the power of tests to explain market reaction to auditor changes. We introduce the OLS post-LASSO method for model development into the auditor change literature. This method may prove useful to future researchers by providing a more rigorous test of the significance of whatever variables are of particular interest in their research.

\section{Methods}

\subsection{Creating a union set of variables from previous literature}

We construct a superset of variables associated with the market reaction to auditor changes by considering extant research studies on this topic. We begin with the auditor change literature review of Stefaniak et al. (2009), supplemented with searching through research indices, such as Google Scholar. (Our focus in this literature search is on empirical papers and models, so we do not include Teoh's (1992) analytical modeling paper in our existing empirical studies table (Table 1) related to market reactions to auditor changes). The list of variables associated with market reaction to auditor change announcements found in the literature is documented on Table 1. The columns in the table are arranged chronologically (most recent first) by date of publication, while the variables shown in the rows are presented in the order of most common use. There are a total of 29 variables used in the existing literature, with variables measuring movement between Big $\mathrm{N}$ and non-Big $\mathrm{N}$ being the most commonly used. These variables are presented in Table 1.

Table 1

Union of Variables from Extant Literature

$\mathrm{X}$ indicates the variable is used in the study. Significant variables in the individual published studies are indicated in bold and underlined.

\begin{tabular}{|c|c|c|c|c|c|c|c|c|c|c|c|c|c|c|}
\hline \multicolumn{2}{|l|}{ Authors } & 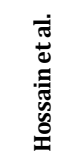 & 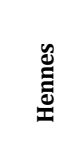 & 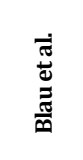 & 营 & 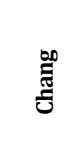 & 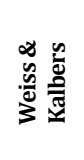 & 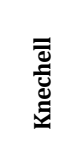 & 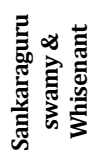 & 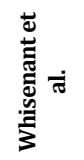 & 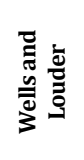 & $\frac{4}{\square}$ & 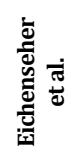 & 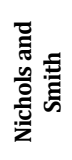 \\
\hline \multicolumn{2}{|c|}{\begin{tabular}{|l} 
Publication year \\
\end{tabular}} & 2014 & 2013 & 2013 & 2012 & 2010 & 2008 & 2007 & 2004 & 2003 & 1997 & 1994 & 1989 & 1982 \\
\hline \begin{tabular}{|l|} 
Max. R- \\
squared
\end{tabular} & & 0.029 & N/A & N/A & 0.03 & 0.075 & $\mathrm{~N} / \mathrm{A}$ & 0.051 & 0.018 & 0.04 & 0.04 & 0.281 & $\mathrm{~N} / \mathrm{A}$ & N/A \\
\hline \multicolumn{15}{|l|}{ Variables: } \\
\hline $\begin{array}{l}\text { Downward } \\
\text { shift }\end{array}$ & 7 & & $\mathrm{X}$ & $\underline{\mathbf{x}}$ & $\underline{\mathbf{x}}$ & $\underline{\mathbf{X}}$ & & $\underline{\mathbf{x}}$ & & & & $\mathrm{X}$ & $\underline{\mathbf{x}}$ & $\mathrm{X}$ \\
\hline Upward shift & 7 & & $\mathrm{X}$ & & $\underline{\underline{\mathbf{X}}}$ & $\underline{\underline{\mathbf{X}}}$ & & $\underline{\underline{\mathbf{X}}}$ & & & & $\mathrm{X}$ & $\underline{\underline{\mathbf{X}}}$ & $\underline{\underline{\mathbf{X}}}$ \\
\hline \begin{tabular}{|l|} 
Client size \\
(Assets)
\end{tabular} & 5 & $\underline{\mathbf{X}}$ & & & & $\mathrm{X}$ & & $\mathrm{X}$ & & & $\mathrm{X}$ & $\underline{\mathbf{X}}$ & & \\
\hline Resign & 5 & $\underline{\mathbf{X}}$ & $\underline{\mathbf{X}}$ & $\underline{\mathbf{X}}$ & & & $\underline{\mathbf{X}}$ & $\mathrm{X}$ & & $\underline{\mathbf{X}}$ & & & & \\
\hline \begin{tabular}{|l|}
$\begin{array}{l}\text { Auditor/client } \\
\text { disagreement }\end{array}$ \\
\end{tabular} & 4 & & & $\underline{X}$ & $\underline{\mathbf{X}}$ & & & $\mathrm{X}$ & $\mathrm{X}$ & $\underline{\mathbf{X}}$ & & & & \\
\hline Lateral shift & 4 & & $\underline{\mathbf{X}}$ & & & $\underline{\underline{X}}$ & $\underline{\mathbf{X}}$ & & & & & & $\mathrm{X}$ & \\
\hline \begin{tabular}{|l|} 
Managerial \\
ownership
\end{tabular} & 3 & & & & & & & $\mathrm{X}$ & & & & $\underline{\mathbf{X}}$ & $\underline{\mathbf{X}}$ & \\
\hline $\begin{array}{l}\text { Accelerated } \\
\text { filer }\end{array}$ & 2 & & & & $\mathrm{X}$ & & $\underline{\mathbf{X}}$ & & & & & & & \\
\hline \begin{tabular}{|l|} 
Client distress \\
\end{tabular} & 2 & & & & $\mathrm{X}$ & & & $\mathrm{X}$ & & & & & & \\
\hline Fee/fee change & 2 & & & & $\mathrm{X}$ & $\mathrm{X}$ & & & & & & & & \\
\hline Fourth Quarter & 2 & & & & $\underline{\mathbf{X}}$ & & & $\underline{\mathbf{X}}$ & & & & & & \\
\hline \begin{tabular}{|l} 
IC \\
weakness/IC \\
reportable \\
event
\end{tabular} & 2 & & & & & $\mathrm{X}$ & & & & $\underline{\mathbf{X}}$ & & & & \\
\hline \begin{tabular}{|l|} 
Industry \\
specialist
\end{tabular} & 2 & & & & & $\underline{\mathbf{X}}$ & & $\underline{\mathbf{X}}$ & & & & & & \\
\hline $\begin{array}{l}\text { Reportable } \\
\text { event }\end{array}$ & 2 & $\underline{x}$ & & & & & & & $\mathrm{X}$ & & & & & \\
\hline \begin{tabular}{|l|} 
Accruals \\
quality
\end{tabular} & 1 & & & & & $\mathrm{X}$ & & & & & & & & \\
\hline $\begin{array}{l}\text { Audit } \\
\text { committee } \\
(\mathrm{Y} / \mathrm{N})\end{array}$ & 1 & & & & & & & & & & & & $\mathrm{X}$ & \\
\hline Auditor tenure & 1 & & & & & & & $\underline{\mathbf{X}}$ & & & & & & \\
\hline Free cash flow & 1 & $\mathrm{X}$ & & & & & & & & & & & & \\
\hline
\end{tabular}




\begin{tabular}{|c|c|c|c|c|c|c|c|c|c|c|c|c|c|c|}
\hline \multicolumn{2}{|l|}{ Authors } & 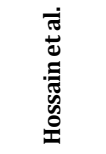 & ֻٕ: & 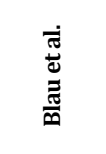 & 䒿 & 哭 & 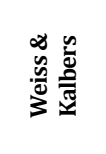 & 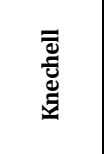 & 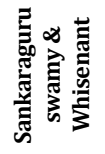 & 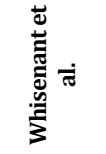 & 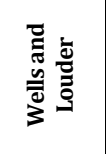 & $\frac{x}{\underline{0}}$ & 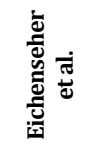 & 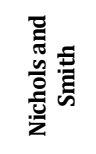 \\
\hline \multicolumn{2}{|c|}{ Publication year } & 2014 & 2013 & 2013 & 2012 & 2010 & 2008 & 2007 & 2004 & 2003 & 1997 & 1994 & 1989 & 1982 \\
\hline $\begin{array}{l}\text { Going concern } \\
\text { opinion }\end{array}$ & 1 & & & & & $\underline{\mathbf{X}}$ & & & & & & & & \\
\hline Growth & 1 & $\underline{\mathbf{X}}$ & & & & & & & & & & & & \\
\hline \begin{tabular}{|l|} 
Change \\
disclosed In 8- \\
$\mathrm{K}$ \\
\end{tabular} & 1 & & & & & & & & & & $\mathrm{X}$ & & & \\
\hline $\begin{array}{l}\text { Non verifiable } \\
\text { reason }\end{array}$ & 1 & & & & & & & & $\underline{\mathbf{X}}$ & & & & & \\
\hline Reason & 1 & & & & & & & & & & $\mathrm{X}$ & & & \\
\hline $\begin{array}{l}\text { Reason (Non- } \\
\text { red flag) }\end{array}$ & 1 & $\mathrm{X}$ & & & & & & & & & & & & \\
\hline $\begin{array}{l}\text { Reason (Red } \\
\text { flag) }\end{array}$ & 1 & $\underline{X}$ & & & & & & & & & & & & \\
\hline $\begin{array}{l}\text { Reportable } \\
\text { event (f/s } \\
\text { Reliability) } \\
\end{array}$ & 1 & & & & & & & & & $\underline{\mathbf{X}}$ & & & & \\
\hline Restatement & 1 & & & & & $\mathrm{X}$ & & & & & & & & \\
\hline $\begin{array}{l}\text { Restatement } \\
\text { size }\end{array}$ & 1 & & $\underline{X}$ & & & & & & & & & & & \\
\hline ROA & 1 & $\underline{\mathrm{X}}$ & & & & & & & & & & & & \\
\hline $\begin{array}{l}\text { Verifiable } \\
\text { reason }\end{array}$ & 1 & & & & & & & & $\mathrm{X}$ & & & & & \\
\hline Sample siz & & 3355 & 329 & 409 & 236 & 1824 & 2237 & 318 & 1015 & 1264 & 86 & 50 & 87 & 51 \\
\hline Sample peri & & $\begin{array}{c}2004 \text { to } \\
2010\end{array}$ & $\begin{array}{c}1997 \text { to } \\
2010\end{array}$ & $\begin{array}{l}2005 \text { to } \\
2006\end{array}$ & $\begin{array}{c}2003 \text { to } \\
2008\end{array}$ & \begin{tabular}{|c|}
2000 to \\
2006
\end{tabular} & $\begin{array}{l}2000 \text { to } \\
2007\end{array}$ & $\begin{array}{c}2000 \text { to } \\
2003\end{array}$ & $\begin{array}{c}1993 \text { to } \\
1996\end{array}$ & $\begin{array}{c}1993 \text { to } \\
1996\end{array}$ & $\begin{array}{c}1988 \text { to } \\
1991\end{array}$ & $\begin{array}{c}1986 \text { to } \\
1987\end{array}$ & $\begin{array}{c}1980 \text { to } \\
1982\end{array}$ & $\begin{array}{c}1972 \text { to } \\
1979\end{array}$ \\
\hline
\end{tabular}

\subsubsection{Variables excluded from our analyses}

In applying the variables selection methods, we do not include some of the variables used to model the cumulative abnormal returns (CARs) associated with auditor change announcements. We omit certain variables from our analyses for two reasons: multiple related variables that represent linear combinations and older variables that are no longer relevant.

Multiple related variables: Some variables considered in previous research represent a combination of variables already included in our models. For example, we do not include a variable for lateral shifts among CPA firm tiers. We do include upward (e.g., from smaller firms to Big 4) and downward shifts (e.g., from Big 4 to smaller firms). Inclusion of the lateral shift category would have resulted in a linear combination of variables, violating an assumption of regression. We therefore exclude lateral changes. The coefficient on the upward and downward shift variables thus measures the effect of an upward or downward auditor change relative to lateral changes.

Relevance of older variables in the current disclosure environment: Three variables measure constructs that are no longer relevant in the current regulatory structure. First, Eichenseher et al. (1989) include a variable measuring whether the company changing auditors had an audit committee. The SarbanesOxley Act of 2002 ( $\$ 301$ ) mandates that "The audit committee of each issuer ... shall be directly responsible for the appointment, compensation, and oversight of the work of any registered public accounting firm employed by that issuer." Audit committees therefore always have the responsibility for managing the auditor relationship throughout most of our sample period. Second, Wells and Louder (1997) include a variable for whether the auditor change was disclosed in an 8-K filing. Since at least 2004, registrants are required to file an 8-K to notify investors of a change in their auditors (SEC, 2004). This variable is therefore also no longer relevant in the current environment. Sankaraguruswamy and Whisenant (2004) and Wells and Louder (1997) include three measures related to the disclosure of various reasons for auditor change. Since the time period of the data used in these previous studies, there is more consistent disclosure related to auditor changes. We therefore rely on the more recent "reason" variables developed and used in the models of Hennes (2013) and Hossain et al. (2014).

\subsubsection{Variables adapted from the list from the previous literature}

We adapt some variables in the existing literature based on a more current institutional environment. The upward change variable, which has various measures from Big $8 \mathrm{v}$. non-Big 8 (e.g., Nicholas and Smith 1982), to Big 4, Second 2 (BDO and Grant Thornton) and other firms (Chang et al. 2010), to Big 4, Next 4, and Smaller firms (Cullinan et al. 2012) to Big 4/5/6 v. non-Big 4/5/6 (Hennes 2014). We adopt the three-tier structure used by the U.S. Government Accountability Office (US GAO, 2008). These three tiers consist of the Big 4 (Deloitte, Ernst \& Young, PricewaterhouseCoopers, and KMPG), mid-sized firms (BDO, 
Grant Thornton, RSM/McGladrey and Crowe Chizek), and small firms. Upward shifts are measured as 1 if the client moved from a small firm to a mid-sized firm, or from a mid-sized to a Big 4 firm. Upward shift is measured as 2 if the client moved from a small firm to a Big 4. Downward shifts are measured similarly, but in reverse. Upward and downward shifts are both measured as 0 if the client's predecessor and successor auditor were both in the same tier.

There are two variables for which we develop two measures each. First, return on assets (ROA) was measured by Hossain et al. (2014) based on income before interest and taxes. We use Hossain's measure as well as the more traditional finance measure of ROA in which income is based on earnings before extraordinary items. Second, most of the extant literature measures size based on assets (i.e., an accounting measure of size). Finance literature suggests that the market reactions to other events may depend on the market capitalization (e.g., Ikenberry et el. 1995), not just size as measured by the financial statements. We therefore include both total assets and total market capitalization among the variables in our model development. The set of variables used for our model development, and their measurement is presented in Table 2 .

Table 2

Variables used for model building

\begin{tabular}{|c|c|c|}
\hline Variable description & Variable name & $\begin{array}{c}\text { Variable } \\
\text { Definition/measurement }\end{array}$ \\
\hline Upward shift & V_UPWARD_SHIFT & $\begin{array}{l}1 \text { if moving up one CPA firm tier; } 2 \text { if } \\
\text { moving up two tiers (i.e., from small } \\
\text { firm to Big 4), } 0 \text { otherwise }\end{array}$ \\
\hline Downward shift & V_DOWNWARD_SHIFT & $\begin{array}{l}1 \text { if moving down one CPA firm tier; } \\
2 \text { if moving up two tiers (i.e., from } \\
\text { Big } 4 \text { to small firm), } 0 \text { otherwise }\end{array}$ \\
\hline Industry specialist & V_INDUSTRY_SPECIALIST & $\begin{array}{l}1 \text { if predecessor auditor was city- } \\
\text { level specialist, } 0 \text { otherwise }\end{array}$ \\
\hline Resign & AUDITOR_RESIGNED & 1 if auditor resigned, 0 otherwise \\
\hline Fourth Quarter & V_FOURTH_QUARTER & $\begin{array}{l}1 \text { if auditor change occurred in } 4^{\text {th }} \\
\text { quarter of fiscal year, } 0 \text { otherwise }\end{array}$ \\
\hline Client size (Assets) & V_CLIENT_SIZE_ASSETS & $\begin{array}{l}\text { Total assets preceding auditor } \\
\text { change }\end{array}$ \\
\hline Client Size (Market Value) & V_CLIENT_SIZE_MARKET_VALUE & $\begin{array}{l}\text { Total market value preceding } \\
\text { auditor change }\end{array}$ \\
\hline $\begin{array}{l}\text { Disagreement between auditor } \\
\text { and client }\end{array}$ & AUD_CO_DISAGREE & $\begin{array}{l}1 \text { = Auditor/client disagreement, } 0 \\
\text { otherwise }\end{array}$ \\
\hline Client distress & V_ALTMAN_Z_SCORE & Altman Z score \\
\hline Fee/fee change & V_FEE_CHANGE & $\begin{array}{l}\text { Audit fee change from predecessor } \\
\text { to successor auditor }\end{array}$ \\
\hline Managerial ownership & $\begin{array}{l}\text { V_MANAGERIAL_OWNERSHIP_F } \\
\text { S }\end{array}$ & $\begin{array}{l}\text { Percentage of shares held by } \\
\text { management and directors }\end{array}$ \\
\hline Auditor tenure & V_AUDITOR_TENURE & $\begin{array}{l}\text { Length of relationship between } \\
\text { predecessor auditor and client }\end{array}$ \\
\hline Accruals quality & V_DISC_AQ & $\begin{array}{l}\text { Discretionary accruals in period } \\
\text { preceding auditor change }\end{array}$ \\
\hline Going concern opinion & DISMISSED_GC & $\begin{array}{l}1 \text { if going concern opinion issued by } \\
\text { predecessor auditor }\end{array}$ \\
\hline IC weakness/IC reportable event & ISS_IC_REPORTABLE & $\begin{array}{l}1 \text { if internal control reportable } \\
\text { event, } 0 \text { otherwise }\end{array}$ \\
\hline Restatement & ISS_RESTATE_FINS & $\begin{array}{l}1 \text { if restatement in period preceding } \\
\text { auditor change }\end{array}$ \\
\hline Accelerated filer & IS_ACCEL_FILER & 1 if accelerated filer, 0 otherwise \\
\hline Reason (Red flag) & V_REASON_RED_FLAG & $\begin{array}{l}1 \text { if reason for dismissal is red flag } \\
\text { (Going concern opinion, } \\
\text { restatement, SEC investigation), } 0 \\
\text { otherwise }\end{array}$ \\
\hline Reason (non-red flag) & V_REASON_NON_RED_FLAG & $\begin{array}{l}1 \text { if reason provided for dismissal } \\
\text { other than red flag reason, } 0 \\
\text { otherwise }\end{array}$ \\
\hline Reportable event (f/s Reliability) & ISS_ACCOUNTING & $\begin{array}{l}1 \text { if reason for dismissal is an } \\
\text { accounting issue or restatement, } 0\end{array}$ \\
\hline
\end{tabular}




\begin{tabular}{|l|l|l|}
\hline \multicolumn{1}{|c|}{ Variable description } & \multicolumn{1}{|c|}{ Variable name } & \multicolumn{1}{c|}{$\begin{array}{c}\text { Variable } \\
\text { Definition/measurement }\end{array}$} \\
\hline & & otherwise \\
\hline Growth & V_GROWTH & Percentage change in total assets \\
\hline ROA & V_RETURN_ON_ASSETS & $\begin{array}{l}\text { Return on Assets in period } \\
\text { preceding auditor change. Income } \\
\text { measured as income before } \\
\text { extraordinary items. }\end{array}$ \\
\hline H-ROA & V_HOSSAIN_RETURN_ON_ASSET & $\begin{array}{l}\text { Return on Assets in period } \\
\text { preceding auditor change. Income } \\
\text { measured as income before interest } \\
\text { and taxes. }\end{array}$ \\
\hline Free cash flow & S & $\begin{array}{l}\text { Free cash flow in period preceding } \\
\text { auditor change }\end{array}$ \\
\hline
\end{tabular}

\subsection{Data gathering process}

We obtain data from Audit Analytics' auditor change database for all auditor changes from January 7, 2001 to May 1, 2018. The number of auditor changes among publicly-traded companies with GVKEYs (for matching to other databases) was 6,942. We then match these observations to CRSP (for measure of cumulative abnormal returns), Compustat (for many of the model variables related to client financial issues), other Audit Analytics Databases (for model variables related to the auditor and audit/client relationship) and to Factset (for measurement of managerial ownership). We also remove auditor changes in which Arthur Andersen was the previous auditor (In common with other auditor change literature (Knechell et al. 2007), we exclude changes in which Arthur Andersen was the former auditor, as these changes were likely due to the collapse of Andersen in 2002). Based on the data restrictions, our analyses are based on 1,133 auditor change observations.

Our analysis consists of three main processes. First, we test models developed in other research using our data. In effect, this is a replication of the other research models using a different data set. Second, we implement the ordinary least squares regression (OLS) post-LASSO method proposed by Belloni and Chernozhukov (2013). This method involves running a LASSO (Least Absolute Shrinkage Selection Operator) analysis with cross validation for variable selection from the union of variables obtained from prior studies and using the selected variables as regressors in an OLS model.

\subsection{Models from previous literature used for basic OLS comparison}

We develop models in which the dependent variable is the cumulative abnormal return (CAR) associated with the auditor change. When comparing our models to the previous literature, we considered a limited group of previous studies. Beginning with the total list of studies, we make exclusions from the existing studies for model comparison for three main reasons: (1) there was no model presented in the previous literature, (2) there were material restrictions on the samples used in the previous studies, and (3) the data was from earlier periods and thus were not comparable to data used in our study.

There were a number of studies that categorized observations based on some characteristics of interest and compared the CARs between/among the categories, but did not present regression models. For example, Hennes et al. (2013) considered whether the market reaction was stronger for auditor resignation relative to auditor dismissals, but did not use a regression model to explain variation among the CARs. Weiss and Kalbers (2008) also considered particular characteristics of the auditor change, including whether the client was an accelerated filer and whether the client moved to an auditor in a different tier (e.g., from Big 4 to smaller firm) and also did not present a regression model.

Other extant papers focused on particular issues, and their samples were therefore restricted to certain types of auditor changes. For example, Knechell, et al. (2007) considered only auditor changes associated with an industry audit specialist. Hennes et al. (2013) considered only auditor changes following restatements. Because our sample is more comprehensive, our models are not directly comparable to these models based on purposefully-limited samples.

Finally, some published papers contained models based on data that is materially older than our data. This data often was from periods before there was standardized disclosure of auditor changes. These older studies include: Wells and Louder 1997; Klock 1994; Eichenseher et al. 1989; and Nichols and Smith 1982 (the years of data considered in these older studies ranged from 1972 to 1991). These older studies also had much smaller sample sizes (ranging in size from 50 to 87 observations). The nature of these small samples was not meaningfully comparable to our larger and more recent observations.

Based on these model exclusions, we run OLS regressions using the main variables from the studies of Hossain et al. (2014), Cullinan et al. (2012), Chang et al. (2010), and Sankaraguruswamy and Whisenant (2004). We calculate cumulative abnormal returns around the auditor change filing date with an event 
window of $[-3,3]$, employing the market model with a 180-day estimation period, at least 130 days of returns and a 16-day gap. The results from these basic OLS regression models are presented in Table 3. The Rsquared values are very low, ranging from 0.003 to 0.010 . The low explanatory power of these models suggests that there may be value in using other methods, such as OLS post-LASSO to select variables to develop models with more explanatory power.

Table 3

OLS Regressions using models from Prior Studies in the Literature

We run OLS regressions of the following form using the variables that each designated study included in its analysis.

$$
y_{i}=\beta_{i}+\sum_{j=1}^{p} \beta_{j} x_{i j}+\varepsilon_{i}
$$

\begin{tabular}{|c|c|c|c|c|}
\hline & \multicolumn{4}{|c|}{ Using variables from the models of: } \\
\hline & $\begin{array}{r}\text { Whisenant, et } \\
\text { al. (2004) }\end{array}$ & $\begin{array}{r}\text { Chang, et al } \\
(2010)\end{array}$ & $\begin{array}{r}\text { Cullinan, et al. } \\
\text { (2012) }\end{array}$ & $\begin{array}{r}\text { Hossain, et al. } \\
\text { (2014) }\end{array}$ \\
\hline Intercept & $\begin{array}{l}-0.0009 \\
(-0.248)\end{array}$ & $\begin{array}{l}-0.0184 \\
(-1.507)\end{array}$ & $\begin{array}{l}-0.0023 \\
(-0.326)\end{array}$ & $\begin{array}{r}-0.0066 \\
(-0.797)\end{array}$ \\
\hline V_UPWARD_SHIFT & & $\begin{array}{r}0.0159^{* *} \\
(2.293)\end{array}$ & $\begin{array}{l}0.0111^{*} \\
(2.293)\end{array}$ & \\
\hline V_DOWNWARD_SHIFT & & $\begin{array}{r}-0.0056 \\
(-0.566)\end{array}$ & $\begin{array}{r}-0.0077 \\
(-0.566)\end{array}$ & \\
\hline V_INDUSTRY_SPECIALIST & & $\begin{array}{r}0.0024 \\
(0.348)\end{array}$ & & \\
\hline AUDITOR_RESIGNED & $\begin{array}{r}0.0034 \\
(0.448)\end{array}$ & & & $\begin{array}{r}0.0046 \\
(0.601)\end{array}$ \\
\hline V_FOURTH_QUARTER & & & $\begin{array}{r}0.0084 \\
(0.348)\end{array}$ & \\
\hline V_CLIENT_SIZE_ASSETS & & $\begin{array}{r}0.0022 \\
(1.154)\end{array}$ & & $\begin{array}{r}0.0004 \\
(0.272)\end{array}$ \\
\hline \multicolumn{5}{|c|}{ V_CLIENT_SIZE_MARKET_VALUE } \\
\hline AUD_CO_DISAGREE & $\begin{array}{r}-0.0151 \\
(-0.564)\end{array}$ & & $\begin{array}{r}-0.0256 \\
(1.154) \\
\end{array}$ & \\
\hline V_ALTMAN_Z_SCORE & & & $\begin{array}{r}4.7648 \\
(0.348) \\
\end{array}$ & \\
\hline V_FEE_CHANGE & & $\begin{array}{r}0.2894 \\
(0.858)\end{array}$ & $\begin{array}{r}0.0147 \\
(0.858)\end{array}$ & \\
\hline \multicolumn{5}{|c|}{ V_MANAGERIAL_OWNERSHIP_FS } \\
\hline \multicolumn{5}{|l|}{ V_AUDITOR_TENURE } \\
\hline \multicolumn{5}{|l|}{ V_DISC_AQ } \\
\hline DISMISSED_GC & & $\begin{array}{l}-0.0013 \\
(-0.100)\end{array}$ & & \\
\hline ISS_IC_REPORTABLE & $\begin{array}{r}-0.0093 \\
(-1.162)\end{array}$ & $\begin{array}{r}-0.0134 \\
(-1.639)\end{array}$ & & $\begin{array}{r}-0.0090 \\
(-1.108)\end{array}$ \\
\hline ISS_RESTATE_FINS & & $\begin{array}{l}-0.0049 \\
(-0.324) \\
\end{array}$ & & \\
\hline \multicolumn{5}{|l|}{ V_RESTATEMENT_SIZE } \\
\hline IS_ACCEL_FILER & & & $\begin{array}{l}-0.0074 \\
(-0.100)\end{array}$ & \\
\hline V_REASON_RED_FLAG & & & & $\begin{array}{r}-0.0052 \\
(-0.493)\end{array}$ \\
\hline V_REASON_NON_RED_FLAG & & & & $\begin{array}{r}-0.0014 \\
(-0.493)\end{array}$ \\
\hline ISS_ACCOUNTING & $\begin{array}{l}-0.0020 \\
(-0.110)\end{array}$ & & & \\
\hline V_GROWTH & & & & $\begin{array}{r}0.0037^{* *} \\
(2.172)\end{array}$ \\
\hline V_RETURN_ON_ASSETS & & & & $0.0153^{* *}$ \\
\hline
\end{tabular}




\begin{tabular}{|l|r|r|r|r|}
\hline & \multicolumn{3}{|c|}{ Using variables from the models of: } \\
\hline & $\begin{array}{r}\text { Whisenant, et } \\
\text { al. (2004) }\end{array}$ & $\begin{array}{r}\text { Chang, et al } \\
\text { (2010) }\end{array}$ & $\begin{array}{r}\text { Cullinan, et al. } \\
\text { (2012) }\end{array}$ & $\begin{array}{r}\text { Hossain, et al. } \\
\text { (2014) }\end{array}$ \\
\hline & & & & $(2.198)$ \\
\hline V_HOSSAIN_RETURN_ON_ASSETS & & & & \\
\hline V_FREE_CASH_FLOW & & & & -0.0092 \\
\hline N & 1133 & 1133 & 1133 & 1133 \\
\hline R-squared & 0.003 & 0.009 & 0.038 & 0.010 \\
\hline F-statistic & 0.7286 & 1.256 & 1.357 & 1.683 \\
\hline
\end{tabular}

\subsection{OLS Post-LASSO Analysis}

OLS post-LASSO is a two-step process. In the first step, the LASSO method is used to identify variables that are appropriate to include in a regression analysis. LASSO proposed by Tibshirani (1996) is a method for shrinkage and selection of variables to be used in OLS regression analyses. Given that the data are denoted by

$$
\left(\mathbf{x}^{\mathrm{i}}{ }_{y_{1}}\right)_{s} i=1,2_{s} \cdots{ }_{s} N_{s} \text { where } \mathbf{x}^{\mathrm{i}}=\left(x_{i \mathbb{1} v^{\cdots}}, x_{s} x_{i p}\right)^{T}
$$

are the values of the independent variables and $y_{1}$ are the values of the dependent variable. $N$ and $p$ represent the number of observations and the number of independent variables, respectively. If the predictor variables are standardized such that:

$\sum_{i=1}^{W} y_{i}=0, \quad \sum_{i=1}^{W} x_{i j}=0, \quad \sum_{i=1}^{W} x_{i j}^{2}=1, \quad$ for $j=1,2, \cdots, p$,

the LASSO estimate is obtained by using the following formulation of an optimization problem:

$\hat{\beta}=\underset{\beta}{\arg \min }\left[\frac{1}{2} \sum_{i=1}^{N}\left(Y_{i}-\beta_{i}-\sum_{j=1}^{p} \beta_{j} x_{i j}\right)^{2}+\lambda \sum_{j=1}^{p}\left|\beta_{j}\right|\right] x$

where $\sum_{j=1}^{p}\left|\beta_{j}\right|$ is the $L_{1}$ LASSO penalty and $\lambda \geq 0$ is a tuning parameter.

In our study, $y_{i}$ are the cumulative abnormal returns (CARs) and $\mathbf{x}$ represents the vector of explanatory variables used in previous research studies in the literature, and $\beta_{0}, \beta_{0}, \ldots, \beta_{p}$ are the coefficients to be estimated by solving the above optimization problem. The minimization problem in equation (2) represents a trade-off between obtaining coefficient estimates that fit the data well with the first term in the square brackets and shrinking the magnitude of the coefficient estimates toward zero through the second term, which represents a shrinkage penalty. The parameter $\lambda$ strikes a balance between the two terms where larger values of $\lambda$ increase the shrinkage penalty and the regression produces coefficient estimates that are closer to zero.

\section{Results}

Table 4 presents the variables selected using a $\lambda$ value obtained through the LASSOCV analysis with 4-fold cross validation. In this process, 11 variables were selected, including some of the most common variables, such as those measuring movement between tiers of auditors. Some less commonly used variables were also machine-selected for inclusion, such as ROA and discretionary accruals, both of which are used in only one of the 12 previous studies considered.

Table 4

Variable Selection Using LASSOCV

Using the variables selected by LASSOCV, we run an OLS model to examine the determinants of the market response to auditor change filings. Dependent variable is the cumulative abnormal return represented by the variable name, MMod_180_60_16_3_3.

Data are denoted by $\left(\mathbf{x}^{\hat{i}}, y_{1}\right), i=1,2, \cdots, N_{x}$ where $\mathbf{x}^{\hat{i}}=\left(x_{i 1}, \cdots, x_{i p}\right)^{T}$ are the values of the independent variables and $y_{i}$ are the values of the dependent variable. $N$ and $p$ represent the number of observations and the number of independent variables, respectively. If the predictor variables are standardized such that:

$$
\sum_{i=1}^{W} y_{i}=0, \quad \sum_{i=1}^{N} x_{i j}=0, \quad \sum_{i=1}^{W} x_{i j}^{2}=1, \quad \text { for } j=1,2, \cdots, p,
$$


the LASSO estimate is obtained by using the following formulation of an optimization problem:

$$
\hat{\beta}=\underset{\beta}{\arg \min }\left[\frac{1}{2} \sum_{i=1}^{N}\left(y_{i}-\beta_{i}-\sum_{j=1}^{p} \beta_{j} x_{i j}\right)^{2}+\lambda \sum_{j=1}^{p}\left|\beta_{j}\right|\right] x
$$

where $\sum_{j=1}^{p}\left|\beta_{j}\right|$ is the $L_{1}$ LASSO penalty and $\lambda \geq 0$ is a tuning parameter.

\begin{tabular}{|c|c|}
\hline Intercept & 0.0 \\
\hline V_UPWARD_SHIFT & 0.00350 \\
\hline$V_{-} D O W N W A R D \_S H I F T$ & -0.00094 \\
\hline$V_{-}$FOURTH_QUARTER & 0.00098 \\
\hline V_CLIENT_SIZE_ASSETS & 0.00997 \\
\hline$V_{-}$CLIENT_SIZE_MARKET_VALUE & -0.01321 \\
\hline AUD_CO_DISAGREE & -0.00033 \\
\hline$V_{-} F E E_{-} C H A N G E$ & 0.00003 \\
\hline ISS_IC_REPORTABLE & -0.00212 \\
\hline$V_{-}$GROWTH & 0.00463 \\
\hline$V_{-} R E T U R N_{-} O N_{-} A S S E T S$ & 0.00269 \\
\hline$V_{-} D I S C_{-} A Q$ & 0.00632 \\
\hline $\mathrm{N}$ & 1133 \\
\hline Minimum $\lambda$ & 0.0000087 \\
\hline Maximum $\lambda$ & 0.0087 \\
\hline$\lambda$ Selected by Cross Validation & 0.0023 \\
\hline
\end{tabular}

Table 5 present the OLS regression results obtained using the variables selected by the LASSO method. The R-squared in this model (0.051) is materially higher than those presented in Table 3, in which we used the variables selected by previous researchers. The explanatory power of this model is also higher than many of the R-squareds reported by previous researchers when developing their models based on the variables they selected and the individual datasets used in their research. This finding suggests that adoption of the OLS post-LASSO method may more effectively control for other factors associated with market reactions to auditor changes and thus may make findings associated with adding some variable of interest more robust.

Table 5

\section{Determinants of Market Response to Auditor Change Filings}

Using the variables selected by LASSOCV, we run an OLS model to examine the determinants of the market response to auditor change filings. Dependent variable is the cumulative abnormal return. We calculate cumulative abnormal returns around the auditor change filing date with an event window of [-3,3], employing the market model with a 180-day estimation period, at least 130 days of returns and a 16-day gap.

$$
\begin{aligned}
& y=\beta_{0}+\beta_{1} V_{-} U P W A R D \_S H I F T+\beta_{2} V_{-} D O W N W A R D \_S H I F T+\beta_{3} V_{-} F O U R T H_{-} Q U A R T E R+\beta_{4} V_{-} C L I E N T \_S I Z E_{-} A S S E T S \\
& +\beta_{5} V_{-} \text {CLIENT_SIZE_MARKET_VALUE + } \\
& +\beta_{6} A U D_{-} C O \_D I S A G R E E+\beta_{7} V_{-} F E E_{-} C H A N G E+\beta_{8} I S S_{-} I C_{-} R E P O R T A B L E+\beta_{9} V_{-} G R O W T H+\beta_{10} \\
& V_{-} R E T U R N_{-} O N_{-} A S S E T S+\beta_{11} V_{-} D I S C_{-} A Q+\varepsilon
\end{aligned}
$$

\begin{tabular}{|l|r|}
\hline \multicolumn{1}{|c|}{ Variable } & $\begin{array}{r}\text { roefficient } \\
\text { (t stat.) }\end{array}$ \\
\hline Intercept & -0.0150 \\
& $(-1.202)$ \\
\hline V_UPWARD_SHIFT & $0.0123^{*}$ \\
& $(1.797)$ \\
\hline \multirow{2}{*}{ V_DOWNWARD_SHIFT } & -0.0089 \\
\hline \multirow{2}{*}{ V_FOURTH_QUARTER } & $(-0.922)$ \\
\hline \multirow{2}{*}{ V_CLIENT_SIZE_ASSETS } & 0.0100 \\
& $(1.390)$ \\
\hline V_CLIENT_SIZE_MARKET_VALUE & $0.0185^{* * *}$ \\
\hline
\end{tabular}




\begin{tabular}{|l|r|}
\hline & $(-5.440)$ \\
\hline AUD_CO_DISAGREE & -0.0175 \\
& $(-0.786)$ \\
\hline V_FEE_CHANGE & $0.8124^{* *}$ \\
& $(2.410)$ \\
\hline ISS_IC_REPORTABLE & $-0.0133^{*}$ \\
& $(-1.716)$ \\
\hline \multirow{2}{*}{ V_GROWTH } & $0.0043^{* * *}$ \\
& $(2.565)$ \\
\hline \multirow{2}{*}{ V_RETURN_ON_ASSETS } & 0.0084 \\
& $(1.319)$ \\
\hline V_DISC_AQ & $0.0066^{* * *}$ \\
Number of observations (N) & $(2.743)$ \\
\hline R-Squared & 1133 \\
\hline F statistic & 0.051 \\
\hline
\end{tabular}

\section{Discussion}

\subsection{Discussion of results}

The OLS pos-LASSO regression models presented in Table 5 demonstrate some interesting findings. First, and consistent with the most commonly-examined issue in the auditor-change market-reaction literature, the market reacts positively when clients select a new CPA firm from among firms of a larger size. These results suggest that the market perceives that CPA firms of larger size may enhance the credibility of client financial statements and/or that the willingness of a larger CPA firm to audit the client's financial statements may signal something positive about the client.

There are two size variables that are both highly significant in the models of auditor-change market reactions with opposite signs: companies with more assets are more likely to have a positive market reaction, while companies with a larger market capitalization are likely to have a smaller (percentage) market reaction. These highly significant results suggest that it may be important for researchers to consider both size variables in their model development.

The contrasting results for the two size variables (assets and market capitalization) indicate a more complex relationship between size and market reactions. The assets size measure is based on the financial statements, while the market value is based on the outstanding shares and price of the stock. We could speculate that as the difference between these two size measures grows, this gap tends to signal that the market perceives the company to be more of a growth stock (rather than a value stock). Growth stocks tend to be more volatile, as the market has priced the expectation of rising sales and profits into the shares. Any news about these growth stocks may be perceived as creating greater uncertainty, and thus may be associated with a stronger negative market reaction (Ikenberry 1995).

The discretionary accruals variable is significant and positively related to market reactions to auditor change announcements. Discretionary accruals are generally viewed as a measure of financial reporting quality, with higher discretionary accruals signaling lower quality financial reporting. These results thus suggest that the market perceives good news when a company with lower quality financial reporting changes auditors.

The change in audit fee variable is significant and positive. Higher audit fees will reduce profits and thus may be expected to result in a negative market response. However, higher audit fees could also signal that the new auditor will perform more audit work, and thus potentially suggest closer monitoring by the auditor (Tee et al. 2017) which can enhance the credibility of the audited financial statements. The positive sign on the change in audit fee variable is thus more consistent with the auditor monitoring/financial statement credibility idea.

\subsection{Robustness analysis}

An alternative variables selection model was also used for our analysis: ElasticNet Analysis (Zou and Hastie 2005). The variable selection results were similar to those for LASSO process, except that the fee change variable was not selected for inclusion by ElasticNet. The post-variables-selection regression results also yielded similar results, except the internal control issue variable (ISS_IC_REPORTABLE) was not significant.

\subsection{Limitations}

The effective application of the LASSO requires data to be available for all of the potential variables of interest. Due to varying availability of data, this approach may limit the generalizability of the first-stage variables selection process. Second, these processes may be less useful in a sample that is significantly restricted, such as the sample used by Hennes et al. (2013), whose main focus was on the effect of 
restatements, and whose sample was thereby restricted to auditor changes preceded by accounting restatements.

\section{Conclusions}

The accounting literature has sought to explain the factors associated with the size of market reactions to auditor change announcements since at least 1982. This literature has tended to focus on how an auditor change may relate to the credibility of the financial reporting. Issues related to this credibility have focused on the size of the auditor and whether the auditor is an industry specialist. Research has also considered whether the reasons disclosed for the auditor change may help to explain variation in the size of the market reaction to auditor change. The results of these studies are subject to variation and/or misinterpretation if the model were to include different control variables.

Based on a union of the variables from previous studies, we identified 29 variables that have been used to try to explain cumulative abnormal returns (CARs) associated with auditor change announcements. We then create a new dataset incorporating 25 of these variables that are still relevant (and potentiallyindependent measures) related to auditor changes from 2001 to 2018 . Using this dataset, we re-tested some of the more recent and relevant models in the literature using traditional OLS regression techniques.

We then applied two-stage models in which the variables to be included in a regression models are selected for inclusion at the initial stage based on their potential to measure unique underlying concepts. The variable selections were based on the LASSO methods. The variables selected in the first stage were then used to test OLS Regression models in which CAR was the dependent variable and the independent variables were those selected by LASSO. The regression models with variable selection resulted in material improvement in model fit relative to the models without machine-generated variables selection.

The variables selected by LASSO that were significant in the OLS regression models included some of the more common variables in the literature, including the size of the predecessor and successor auditors, which was used in 7 of the 12 papers considered.

Our study introduces the OLS Post-LASSO selection models into the auditor change literature. Our results suggest that researchers may find it useful to adopt a more formal variable selection process in modeling market reactions. The results would then provide a more robust test of their variable(s) of interest, as other factors may be more effectively controlled.

\section{Acknowledgement}

We gratefully acknowledge helpful comments received from participants at the 2019 American Accounting Association Annual Meeting, especially Joe Johnston, the paper's discussant.

\section{References}

1. Bajari, P., Nekipelov, D., Ryan, S. P. and Yang, M. (2015). "Machine Learning Methods for Demand Estimation", American Economic Review, 105(5), pp. 481-85.

2. Belloni, A. and Chernozhukov, V.. (2013). "Least Squares after Model Selection in High-Dimensional Sparse Models”, Bernoulli, 19(2), pp. 521-547.

3. Belloni, A., Chernozhukov, V. and Hansen, C. (2014), "High-Dimensional Methods and Inference on Structural and Treatment Effects", Journal of Economic Perspectives, 28(2), pp. 29-50.

4. Blau, B. M., Brough, T. J., Smith, J. L., \& Stephens, N. M. (2013), "An examination of short-selling activity surrounding auditor changes.", Journal of Accounting, Auditing \& Finance, 28(4), pp. 348-368.

5. Chang, H., Cheng, C.S.A. and Reichelt. K. J. (2010), "Market Reaction to Auditor Switching from Big 4 to Third-Tier Small Accounting Firms", Auditing: A Journal of Practice \& Theory, 29(2), pp. 83-114.

6. Cullinan, C. P., Du, H. and Zheng, X. (2012), "Barriers to Entry to the Big Firm Audit Market: Evidence from Market Reaction to Switches to Second Tier Audit Firms in the Post-SOX Period", Research in Accounting Regulation, 24(1), pp. 6-14.

7. Derksen, S. and Keselman, H. J. (1992), "Backward, Forward and Stepwise Automated Subset Selection Algorithms: Frequency of Obtaining Authentic and Noise Variables”, British Journal of Mathematical and Statistical Psychology, 45(2), pp. $265-282$.

8. Eichenseher, J. W., Hagigi, M., and Shields, D. (1989), "Market reaction to auditor changes by OTC companies", Auditing:A Journal of Practice \& Theory, 9(1), pp. 29-40.

9. Feng, G., Giglio, S. and Xiu, D. (2019), "Taming the Factor Zoo", Chicago Booth Research Paper No. 17-04. Available at SSRN: https://ssrn.com/abstract=2934020.

10. Freyberger, J., Neuhierl, A. and Weber, M. (2017), "Dissecting Characteristics Nonparametrically". CESifo Working Paper Series No. 6391. Available at SSRN: https://ssrn.com/abstract $=2951057$.

11. Han, Y., He, A., Rapach, D. and Zhou, G. (2018), “What Firm Characteristics Drive US Stock Returns?” Working paper, University of North Carolina. Available at SSRN: https://ssrn.com/abstract=3185335.

12. Harrell F. E. (2001), "Regression Modeling Strategies: With Applications to Linear Models, Logistic Regression, and Survival Analysis", New York: Springer.

13. He, Q., Zhang, H.H., Avery, C.L. and Lin, D.Y. (2016), "Sparse Meta-Analysis with High-Dimensional Data", Biostatistics, 17(2), pp. 205220.

14. Hennes, K. M., Leone, A. J. and Brian P. Mille. (2014), "Determinants and Market Consequences of Auditor Dismissals after Accounting Restatements", The Accounting Review, 89(3), pp. 1051-1082.

15. Hossain, M., Mitra, S. and Rezaee, Z. (2014), "Voluntary Disclosure of Reasons for Auditor Changes and the Capital Market Reaction to Information Disclosure”, Research in Accounting Regulation, 26(1), pp. 40-53.

16. Ikenberry, D., Lakonishok, J. and Vermaelen, T. (1995), "Market Underreaction to Open Market Share Repurchases", Journal of Financial Economics, 39(2-3), pp. 181-208. 
17. Klock, M. (1994), "The Stock Market Reaction to a Change in Certifying Accountant", Journal of Accounting. Auditing and Finance, 9(2), pp. 339-347.

18. Knechel, W. R., Naiker, V. and Pacheco, G. (2007), "Does Auditor Industry Specialization Matter? Evidence from Market Reaction to Auditor Switches", Auditing: A Journal of Practice \& Theory, 26(1), pp. 19-45.

19. Li, Q., Wang, S. Huang, C., Yu, M. and Shao J. (2014), "Meta-Analysis Based Variable Selection for Gene Expression Data", Biometrics, 70(4), pp. 872-880.

20. Liu, F., Dunson, D. and Zou, F. (2010), "High-Dimensional Variable Selection in Meta-Analysis for Censored Data", Biometrics, 67(2), pp. 504-12.

21. Nichols, D. R., and Smith, D. B. (1983), “Auditor Credibility and Auditor Changes”, Journal of Accounting Research, 21(2), pp. 534-544.

22. Rapach, D., Strauss, J., Tu, J. and Zhou, G. (2018), "Industry Return Predictability: A Machine Learning Approach", Available at SSRN: https://ssrn.com/abstract=3120110.

23. Sankaraguruswamy, S. and Whisenant, J. S. (2004), "An Empirical Analysis of Voluntarily Supplied Client-Auditor Realignment Reasons", Auditing: A Journal of Practice \& Theory, 23(1), pp. 107-121.

24. Securities and Exchange Commission (SEC). (2004), Final Rule: Additional Form 8-K Disclosure Requirements and Acceleration of Filing Date", Accessible at: https://www.sec.gov/rules/final/33-8400.htm

25. Securities and Exchange Commission (SEC). (2017), "Exchange Act Form 8-K: Questions and Answers of General Applicability. Accessible at: https://www.sec.gov/divisions/corpfin/guidance/8-kinterp.htm

26. Stefaniak, C. M., Robertson, J. C., and Houston, R. W. (2009), "The causes and consequences of auditor switching: A review of the literature", Journal of Accounting Literature, 28, pp. 47-121.

27. Tee, C. M., Gul, F. A. , Foo, Y-B and Teh, C. G. (2017), "Institutional monitoring, political connections and audit fees: evidence from Malaysian firms", International Journal of Auditing, 21(2), pp. 164-176.

28. Teoh, S. H. (1992), "Auditor independence, dismissal threats, and the market reaction to auditor switches", Journal of Accounting Research, 30(1), pp. 1-23.

29. Tibshirani, R. (1996), "Regression shrinkage and selection via the lasso", Journal of the Royal Statistical Society. Series B (Methodological), 58(1), pp. 267-288.

30. U.S. Government Accountability Office. (2008), "Audits of Public Companies: Continued Concentration in Audit Market for Large Public Companies Does Not Call for Immediate Action" GAO-08-163.

31. Wells, D. W. and Loudder. M. L. (1997), "The Market Effects of Auditor Resignations", Auditing, A Journal of Practice and Theory, 16(1), pp. 138-144.

32. Whisenant, J. S., Sankaraguruswamy, S. and Raghunandan, K. (2003), "Market Reactions to Disclosure of Reportable Events", Auditing, A Journal of Practice and Theory, 22(1), pp. 181-194.

33. Zou, H. and Hastie, T. (2005), "Regularization and variable selection via the elastic net", Journal of the Royal Statistical Society: Series B (Statistical Methodology), 67(2), pp. 301-320. 